\title{
DIREITO E TRANSFOBIA: estudo dos limites sobre a retificação de
}

registro civil de pessoas trans // Gustavo Borges Mariano ${ }^{1}$

\section{Palavras-Chave}

transfobia / cisgenerismo / discurso /

heteronormatividade / direito ao nome

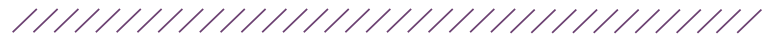

\section{Sumário}

2

A transfobia, o Brasil e o Direito

Caminhos percorridos

3 Heteronormatividade e transfobia

4 A dogmática jurídica: o nome é direito cisgênero?

5 Dados da jurisprudência

6 Discussão: os limites criados pelo Direito

7 Considerações finais

8 Referências

\section{Resumo}

$\mathrm{O}$ artigo pretende analisar o discurso sobre a retificação do registro civil de pessoas trans e como esse discurso forma uma matriz de inteligibilidade sobre elas. O objeto de análise foi a dogmática jurídica dominante e a jurisprudência do Estado de São Paulo. Tanto a dogmática quanto a jurisprudência demonstraram um senso comum teórico dos juristas que apoia a alteração de nome e sexo no registro civil de pessoas transexuais, não de travestis. Com base em Butler, Foucault e Warat, foi possível perceber que não há reconhecimento completo de pessoas trans, porquanto ainda existe um controle jurídico sobre as possibilidades de alterar o registro civil com fundamento na autonomia e dignidade do sujeito. 


\section{LAW AND TRANSPHOBIA: study of the limits on the alteration of}

trans people's civil registry // Gustavo Borges Mariano

\section{Keywords}

transphobia / cisgender / discourse / heteronormativity / right to the name

\section{Resumo}

The paper aims to analyse the discourse about the alteration of trans people's civil registry and how this discourse creates an intelligibility framework about them. The object of analysis was the dominant legal dogmatic and the jurisprudence of the State of São Paulo. Both dogmatic and jurisprudence have demonstrated a jurists' common sense that supports the change of name and sex in the civil registry of transsexual people, not travestis. Based on Butler, Foucault and Warat, it was possible to perceive there is no full recognition of trans people, therefore there still exists a legal control about the possibilities on changing the civil registry grounded on the subject's autonomy and dignity. 


\section{A transfobia, o Brasil e o direito ${ }^{2}$}

Registraram-se 144 (cento e quarenta e quatro) mortes de pessoas trans no Brasil em 2016. 52 (cinquenta e duas) tentativas de homicídio. A idade média de uma pessoa transgênera não passa dos 35 (trinta e cinco) anos e é menos da metade da média nacional de 74,9 (setenta e quatro e nove décimos) anos. E as violências a pessoas trans são naturalizadas e chegam a culpar as vítimas pela agressão (Nogueira; Aquino; Cabral, 2017). Essas, infelizmente, são apenas algumas das contingências de uma vida não-cisgênera no Brasil. Vidas que são vividas com medo, abandono, marginalização e pobreza.

Outro problema social que essas pessoas passam é em relação à incoerência entre seus nomes e seus corpos, por exemplo, no mercado de trabalho, na escola, na família e em outras instituições. Há diversos constrangimentos no cotidiano desses seres humanos por causa de uma discordância entre um documento formal e sua identidade visual, comportamental e cognitiva. Nesse sentido, a transfobia, a aversão e discriminação contra travestis e transexuais, é estrutural e simbólica.

Ao observarmos a Constituição Cidadã e percebermos que um de seus principais escopos é o bem social e a dignidade humana é sua pedra angular, pergunta-se: enquanto pessoas trans não são tratadas como pessoas cisgêneras, nosso direito está garantindo igualdade e justiça? Todos são considerados sujeitos de direitos? Pessoas trans têm suas dignidades garantidas? Essas primeiras provocações em face da Constituição são importantes para se pensar na eficácia de direitos fundamentais de travestis e transexuais, principalmente no que tange à proteção e à promoção da dignidade da pessoa humana.

A questão desse trabalho é: como o discurso jurídico

2 Os dados desse trabalho foram recolhidos até meados de 2017 por isso não a tempo da decisão do STF sobre possibilidade de mudança as menções de nome e sexo de pessoas trans sem modificações corporais ( no julgamento da Ação Direta de Inconstitucionalidade 4275 ) e o subsequente provimento n. 73 , de 28 de junho de 2018 do CNJ que "dispõe sobre a averbação da alteração do prenome e do gênero nos assentos de nascimento e casamento de pessoa transgênero no Registro Civil das Pessoas Naturais". Disponível em: http://www.cnj.jus.br/files/conteudo/arquivo/2018 /06/434a36c27d599882610e933b8505d0f0.pdf. limita as possibilidades de reconhecimento de pessoas trans? $\mathrm{O}$ artigo desenvolverá os seguintes objetivos para trazer elementos para uma possível resposta: reunir as análises dogmáticas sobre o direito de alterar o registro civil; identificar os critérios para decisões no Tribunal de Justiça de São Paulo (TJ-SP); e analisar como o discurso cria uma matriz de inteligibilidade sobre a pessoa trans, seja transexual ou travesti.

\section{Caminhos percorridos}

O caminho metodológico passa pela investigação sobre a transfobia com dados quantitativos e qualitativos; a pesquisa das dogmáticas constitucional, civil e civil-constitucional; o estudo da jurisprudência do Tribunal de Justiça do Estado de São Paulo e a posterior análise do discurso. Por isso, três conceituações serão importantes: as relações de poder imbricadas no discurso jurídico (Warat, 1995, 2004b, 2004c; Foucault, 2013, 2014; Fonseca, 2012); a matriz de inteligibilidade do discurso dominante sobre gênero e sexualidade (Butler, 2000, 2014); e a concepção dominante sobre travestis e transexuais e como ela cria um processo de exclusão desses sujeitos (Jesus, 2012, 2013a, 2013b; V., 2012).

Warat tece uma crítica à forma que a racionalidade jurídica criada pelo discurso jurídico é imaginária (Warat, 1995, p. 104). Ela parte de um modelo ideal de conhecimento, com um núcleo inalterável de valores abstratos, como se esse sistema fosse desconectado da sociedade e ao mesmo tempo para criar uma ordem negando o plural . O autor demonstra a necessidade de um olhar sobre a política que envolve o direito e a dogmática jurídica, principalmente com a explicitação das relações de poder que cruzam seus discursos.

O discurso jurídico dominante tem a pretensão de ser científico, portanto objetivo e neutro. Essa cientificidade jurídica seria isenta de ideologias, como se houvesse uma clara separação entre dóxa e episteme ${ }^{3}$. Não obstante, ele atenta que o "senso comum teórico não deixa de ser uma significação extra-conceitual no interior de um sistema de conceitos, uma ideologia no interior da Ciência, uma dóxa no interior da episte-

3 Dóxa são as opiniões comuns e a episteme, o conhecimento científico. 
me" (Warat, 2004c, p. 30). Esses conhecimentos compartilhados não passariam de imagens que criam ilusões de serem dados "claros, transparentes, que podem ser interpretados, com segurança, mediante uma razão comandada pela intuição" (Warat, 2004c, p. 30). A racionalidade jurídica silenciosamente cria limites para a significação dos seus significantes, como se fosse um processo desconectado da sociedade (Warat, 1995, p. 110). Constrói-se, portanto, uma imagem mítica de direito que trabalha com a verdade de forma legítima.

Os estudos de Warat sobre verdade, poder e saber jurídico, têm como base o pensamento de Foucault. $\mathrm{Na}$ genealogia de Foucault, o filósofo afirma que a imanência da norma se dá pela inexistência da norma em si, pois ela é produzida e também produz efeitos. A norma não pode ser pensada fora de seu campo de discursividade. Nesses trabalhos genealógicos, explora-se como os mecanismos de poder constituem objetos e sujeitos, o que deixa de remeter à distribuição e separação e remete aos mecanismos e estratégias dessa constituição, ou seja, à "normalização" (Fonseca, 2012, p. 62). As verdades criadas por esses mecanismos vão sendo reproduzidas socialmente e se acomodam no senso comum de forma naturalizada, como verdades pressupostas. Ocorre uma fascinação dos sentidos, porquanto as representações são imagens que muitas vezes não permitem o acesso à complexidade das redes de significação e, consequentemente, da ideologia que permeia esses discursos com suas intenções (Warat, 2004b, p. 503). O discurso jurídico é uma ordem simbólica que regula o que pode ser dito. E o que "é dito" é o discurso dominante - pois ele "triunfou" (Warat, 1995, p. 111). O processo de homogeneização discursiva pretende uma ordem e dentro dela o indivíduo encontra significados que podem ser usados. A ficção, portanto, é o que percebemos como real por meio desse enquadramento normativo, enquanto a formação discursiva engendra os corpos em função dos interesses de dominação, podendo excluí-los, por exemplo.

A identidade e o processo de identificação são importantes nesse contexto. Se por um lado temos uma pretensão de estabilidade de um corpo por conta dos significados ditos sobre ele (identidade), tem-se o processo pessoal de relação consigo mesmo a partir das leituras feitas sobre o próprio corpo (identificação). O gênero é uma construção de identidade, que não é estável, "é uma identidade constituída no tempo" (Butler, 2014, p. 38). O gênero é construído com a repetição de atos que são apresentados como necessários, daí seu caráter performativo. Ao mesmo tempo, o gênero é uma norma impossível de se incorporar completamente (Butler, 2014, p. 200). É uma fantasia, um estereótipo, porquanto é uma imagem ideal de ser e existir. O sujeito não é uma essência, por sua natureza. A impossibilidade da constituição completa do ideal de gênero é por conta da identificação. Ao mesmo tempo em que há um discurso que limita as possibilidades de ser baseado na ideia de sexo, o indivíduo tem autonomia e agência para desfazer e refazer as normas de gênero propostas para seu corpo (Butler, 2009). A concepção de sexo é formada por significados de acordo com um pensamento sobre o corpo. Nascer com pênis ou vagina, por exemplo, é o que define se é homem ou mulher, como se não houvesse a possibilidade da pessoa ter outra formação gonadal, outros cromossomos (não a expectativa de $X Y$ e XX) e outra produção de hormônios (todos esses são casos de intersexualidade). Saber sobre certas características do corpo de um ser humano seria uma forma de qualificar os limites de seu comportamento e dividir a sociedade numa ordem de acordo com essas características. Assim, o discurso atinge cada corpo de acordo com o sexo. Isso significa que as práticas e o tratamento desses corpos será diferente de acordo com o que é determinado discursivamente.

A análise do discurso foucaultiana permite os teóricos queer a analisar as condições de possibilidade e as formações discursivas da normalização (FILAX; SUMARA; DAVIS, 2015, p. 134). Esse aporte teórico parte da concepção do discurso como prática. Assim, o que o saber inscreve na realidade não são verdades imutáveis e prontas, as verdades são efeitos do discurso. A atenção desses estudos é sobre como o poder age, quais meios utiliza, quais suas estratégias de produção de sentidos e de normalização dos corpos. Butler, por exemplo, ressalta que a ideia da genealogia não é buscar causas ou origens de categorias de identidade, mas sim perceber como elas são efeitos de instituições, práticas e discursos (Butler, 2014, p. 9). O foco dos estudos queer é relacionar as questões de poder com as técnicas de produção do gênero e 
como o poder organiza os corpos por meio da ideia pré-discursiva de "sexo" como essência (Butler, 2014, p. 25-27; Louro, 2015, p. 84).

Com base nesse aporte teórico é que podemos usar como objeto de estudo os enunciados da dogmática e da jurisprudência que nos possibilitem compreender o senso comum teórico dos juristas. Será possível perceber como identidades transgêneras são produzidas e limitadas pelo discurso jurídico. No meio desse percurso, vozes de pessoas trans aparecerão para guiar as reflexões sobre o Direito. São vozes como essas que clareiam as formas como o Direito também percebe subjetividades dentro de uma matriz de inteligibilidade.

\section{Heteronormatividade e transfobia}

Enquanto todas as pessoas não tiverem acesso a todas as informações, enquanto práticas e vivências forem anuladas por outras, através de livros em que estas histórias não são contadas, continuaremos com os estigmas e orientando os corpos de outras pessoas. (Siqueira, 2016)

Para nosso sistema jurídico, todos os indivíduos no Estado seriam sujeitos de direitos? Historicamente, travestis têm sido excluídas de nossa sociedade por não se enquadrarem no padrão heteronormativo. Foram perseguidas na ditadura, muito conhecidas como "bonecas" e eram entendidas como identidades masculinas (Morando, 2014); muitas migraram para a Europa, onde se sentiam mais respeitadas, mesmo que fosse na prostituição (Vartabedian, 2014). A maioria, 90\% (noventa por cento), trabalha na prostituição atualmente, pois muitas são discriminadas na escola e em entrevistas de trabalho (o que não significa que é um trabalho compulsório para todas); e até hoje muitas travestis e transexuais são mortas no Brasil, sendo o país com mais assassinatos no mundo (Transgender Europe, 2016). Como maneira de enfrentar esse sistema opressor, pessoas transgêneras têm se organizado em movimentos transfeministas, que explicitamente fazem teoria e práxis. Jaqueline Gomes de Jesus aponta alguns dos tópicos necessários para serem abordados em uma luta transfeminista:
(1) redefinição da equiparação entre gênero e biologia; (2) reiteração do caráter interacional das opressões; (3) reconhecimento da história de lutas das travestis e das mulheres transexuais e das experiências pessoais da população transgênero de forma geral como elementos fundamentais para o entendimento do feminismo; e (4) validação das contribuições de quaisquer pessoas, sejam elas transgênero ou cisgênero, o que leva ao fato de que, por sua constituição, o transfeminismo pode ser útil para qualquer pessoa que não se enquadra no modelo sexista (Jesus, 2013a, p. 249).

Os estudos transfeministas sobre gênero têm apontado que há: a) um senso comum heteronormativo compartilhado que segrega as sexualidades "desviantes"; b) corpos que são lidos como abjetos e algumas vidas são passíveis de luto, outras não; e c) que a falta de compreensão sobre identidades não cisgêneras empurrou-as para categorias patologizadas. Essa incompreensão está balizada por uma construção histórica ocidental branca da divisão de corpos entre homens e mulheres. Os mecanismos de manutenção dessas identidades estão diretamente implicados na cisgeneridade: a continuidade e a congruência entre o sexo designado ao corpo com pênis ou vagina e a identidade de gênero da pessoa. Viviane Vergueiro provoca nesse sentido: por que ainda há um espanto e uma curiosidade sobre pessoas não cisgêneras ao mesmo tempo em que não questionam a manutenção de binarismos fixos para os corpos? (Vergueiro, 2012). Com questionamentos epistemológicos como esse, partimos para o estudo de como as relações de poder limitam e criam sujeitos.

A heteronormatividade é o padrão compulsório aos corpos, cada um deve se encaixar em um dos moldes (homem ou mulher), compartilhando uma coerência entre sexo, gênero, desejos e prazer corporal (Butler, 2014, p. 38). Exemplo dessa continuidade entre corpo e comportamento: a pessoa que nasce com cromossomos XY, pênis e escroto (sexo) deve se vestir e se comportar "como homem" (gênero), além de sentir desejo apenas por mulheres (ser heterossexual) e de obter prazer pelo seu órgão genital ${ }^{4}$. As pessoas que

4 Há descontinuidades em qualquer um desses quatro elementos. Existem pessoas que são intersexo (não nascem com genitais em 
se identificam principalmente com a coerência entre sexo designado ao nascimento e seu gênero são as chamadas cisgêneras, o que é colocado como regra pela heterormatividade. A expectativa social heteronormativa é que essa coerência seja exercida a fim de manter "bons costumes" numa visão que pressupõe uma natureza fixa (ou essência) do corpo. Contudo, o corpo não persegue uma lógica formal dentro do caminho sexo-gênero-desejo-prazer.

O termo cisgênero é usado para aquelas pessoas que se identificam com o gênero designado ao nascer. Seu principal uso nesse trabalho será com a variação "cisgenerismo". Cisgenerismo é a ideologia que deslegitima a forma como alguém se identifica sobre seu gênero e seu corpo. $O$ cisgenerismo é uma crítica ao binário essencializante cisgênero/transgênero, pois ele pode invisibilizar e excluir outras identidades que não se encaixam nos binarismos de homem e mulher. "Cisgenerismo pode descrever atos sistêmicos ou individuais que ocorrem em uma variedade de contextos, incluindo aqueles que são hostis ou benevolentes e aqueles que são intencionais ou não" (Ansara; Berger, 2016, p. 1).

Os estudos de gênero demonstram principalmente que há uma desconexão essencial entre a morfologia da pessoa, lida pela ideia de sexo, e a identificação de gênero da pessoa (como homem, mulher, travesti, não-binário, etc.). Assim o gênero seria construído socialmente e o sexo seria um dado biológico. Algumas autoras têm discutido essa dicotomia e questionam se esse sexo também não é construído socialmente. Henrietta Moore está preocupada com a categoria "natureza": se autoras(es) trabalham "gênero" ainda em uma dicotomia com o sexo, como esse é pensado socialmente? Anne Fausto-Sterling aponta que a

que há elementos "masculinos" e "femininos"); aquelas que não se identificam com o gênero imposto ao nascer (transexuais, travestis, transgêneros, hijras, pessoas não-binárias, etc.); aquelas que não sentem atração pelo gênero que "deveria" (gays, lésbicas, bissexuais, pansexuais, assexuais, etc.); por fim, aqueles que não materializam seus desejos apenas através de seus órgãos genitais, mas também por outras regiões corpóreas e também com objetos externos (sexo anal, sadomasoquismo, etc.). Existem, por exemplo, transexuais que são homossexuais, exemplo: uma mulher transexual (que ao nascer foi lida como "homem") que se atrai por muIheres, ela é uma transexual lésbica, pois se identifica como muther e se atrai por mulheres. biologia do corpo pode determinar parte do comportamento, mas que o comportamento pode alterar o funcionamento fisiológico, ou seja, um não atua em detrimento do outro. Yanagisako e Collier já demonstram que apesar da separação entre gênero e sexo e fora de um determinismo biológico, ainda se pressupõe nessa separação que existam diferenças sexuais biológicas binárias sem questionar o imaginário ocidental que significa socialmente o sexo. Moore (1997, p. 825-828) argumenta que o sexo só pode ser percebido dentro do quadro normativo criado pelo Sexo no discurso ocidental com seus parâmetros biomédicos. Além disso, as concepções da biologia sobre o sexo influenciam as construções sociais, como foi o caso da afirmação que os homens têm mais competência em habilidades matemáticas, que influenciou o sistema educacional norte-americano, o que limita culturalmente os horizontes de mulheres sobre suas capacidades (Fausto-Sterling, 1987, p. 71, 74).

Parte da perspectiva de diferenciação sexual foi "cientificamente" construída a partir de meados do século XVII, com alta produção entre os séculos XVIII e XX. Um dos grandes vértices dessa construção histórica é quando Lineu, no século XVIII, elegeu o grupo de mamíferos como Mammalia, centralizando os seios e a fêmea. Lineu, além de cientista, estava envolvido nas campanhas pelo Estado francês contra as amas de leite e em defesa do aleitamento materno, o leite materno era enaltecido, assim como a posição da mulher lactante. Tais campanhas redefiniriam o lugar doméstico para mulheres sob o fundamento da sua "natureza" ser essa (Bento, 2006, p. 113, 120 e 121).

Os sujeitos são atravessados por esses sentidos que naturalizam as diferenças dos sexos em uma política que inferioriza e subordina a mulher e aponta o homem como sujeito universal. A mulher é vista como o oposto, o complemento do homem, por ser diferente e "mais fraca", é "inferior" (Swain, 2010, p. 46). Estar na posição feminina é se encontrar em um lócus social rebaixado, nesse contexto. A instauração e manutenção desse significado permite a dominação masculina.

Os valores diferenciados são reproduzidos sistematicamente através de um esforço social a fim de reiterar comportamentos e pensamentos, o que resulta na continuidade de atos do sujeito que se põe 
em cena ativamente para satisfazer a expectativa de gênero (Connel; Pearse, 2015, p. 39) da padronização subjetiva. Ao mesmo tempo em que há uma incitação da força de desejo dessa performance, há a castração da potência criadora desses corpos (Warat, 2004a), na medida em que não têm acesso imediato ao significado que instaura o desejo de coerência, por isso "o desejo investe contra si mesmo e a favor do fortalecimento do status quo" (Rolnik, 2014, p. 106). Fortalecer o status quo é a consagração da ficção da diferença hierárquica social entre homem e mulher.

Essa produção demonstra que a manifestação corporal não está atrelada às condições reprodutoras de forma natural, mas a significados compartilhados sobre comportamento que determinam estereótipos e regimes de gênero. Por isso a famosa frase de Beauvoir: não se nasce mulher, torna-se. Da mesma forma, não se nasce homem, torna-se.

A heteronormatividade assenta a "diferença dos sexos" para reproduzir uma compreensão de que os corpos sexuados essencialmente "são determinantes do papel e status no social e de que a 'natureza' define a importância dos seres humanos de acordo com a sua biologia. A diferença dos sexos é, portanto, também política, na medida em que sela a desigualdade no social” (Swain, 2010, p. 47). Apesar de o gênero ser uma característica individualizável, ele envolve prazer, reconhecimento, identidade, relações, fronteiras, práticas, identidades, imagens ativamente criadas em processos sociais e Justiça (Connel; Pearse, 2015, p. 43, 84). Isso demonstra que ele é relacional, só se faz em sociedade. Por isso, a instituição da desigualdade com fundamento na diferença em uma hierarquia é resultado de uma trama de relação de poder que se constrói com o discurso sobre o gênero e a sexualidade. Essa construção está imbricada em sua manutenção constante através dos discursos que circundam o saber sobre a verdade do que é ser homem e ser mulher "naturalmente". As categorias vão sendo criadas a fim de manter condições de inteligibilidade sobre os corpos no campo social com as relações de poder.

Butler afirma que a ideia de gênero está atrelada às identidades (conceito ocidental). Seria uma substância do sujeito ser homem ou mulher, como forma de representação de uma "ordem verdadeira das coisas" (Butler, 2014, p. 43). O gênero não só designa e nomeia, mas qualifica o sujeito dentro de uma episteme conceitual, ao mesmo tempo em que cria esse quadro de inteligibilidade. Assim, a pessoa se sentir e se entender como sendo homem ou mulher advém da noção de que seu sexo o define: "a pessoa é um gênero e o é em virtude do seu sexo, do seu sentimento psíquico do eu, e das diferentes expressões desse eu psíquico, a mais notável delas sendo a do desejo sexual" (Butler, 2014, p. 44). Assim, a unidade entre experiência, sexo, desejo e gênero se conforma por meio da heterossexualidade oposicional, que coloca homens e mulheres para se desejaram. Butler, em Problemas de Gênero, não enfoca no laço entre a manutenção necessária da masculinidade do corpo macho e da feminilidade do corpo fêmea, o que seria justamente o cisgenerismo necessário para coerência do gênero. Tal coerência também é uma ficção regulatória do sistema de gênero.

As identidades sexuais que escapam e subvertem os padrões estabelecidos politicamente pelo discurso de matriz heteronormativa são «desviantes» ${ }^{5}$. Pode-se fazer uma primeira separação para fins de análise: orientação sexual se refere às formas de se relacionar sexual e afetivamente (heterossexual, homossexual, bissexual, assexual, etc.), enquanto a identidade de gênero é o gênero com o qual a pessoa se identifica (homem, mulher, travesti, não-binário, bigênero, agênero, etc.).

Nesse trabalho, os sujeitos de direito excluídos são aqueles que não se identificam com o gênero designado no nascimento, sendo que três identidades precisam ser pontuadas: travesti, transexual e transgênero. O conceito "transgênero" pode abarcar a identidade (travestis e transexuais) ou a funcionalidade (drag queens, crossdressers, transformistas, etc.) (Jesus, 2012). Não obstante, tal termo foi rechaçado por militantes em eventos de pessoas transexuais e travestis, porquanto se trata de um termo estrangeiro, pretensiosamente colonizador frente às identidades brasileiras (Carvalho; Carrara, 2013). O

50 termo "queer" foi utilizado na literatura estrangeira para subverter o seu primeiro sentido pejorativo, era usado como xingamento contra gays. Em português significa "estranho", "diferente", "desviante", pois é usado para caracterizar essas identidades que escapam do binarismo de gênero. (Louro, 2015). 
termo transexual também teve sua origem como um estereótipo patologizado pela psiquiatria. De acordo com Jaqueline Gomes de Jesus, entretanto, esse significado é equivocado:

A transexualidade é uma questão de identidade. Não é uma doença mental, não é uma perversão sexual, nem é uma doença debilitante ou contagiosa. [...] Transexuais sentem que seu corpo não está adequado à forma como pensam e se sentem, e querem corrigir isso adequando seu corpo ao seu estado psíquico. Isso pode se dar de várias formas, desde tratamentos hormonais até procedimentos cirúrgicos. (JESUS, 2012, p. 7-8)

Já as travestis "vivenciam papéis de gênero feminino, mas não se reconhecem como homens ou como mulheres, mas como membros de um terceiro gênero ou de um não-gênero" (Jesus, 2012, p. 9) e a psicóloga frisa que a identificação da travesti é mais próxima do feminino, portanto deve-se dirigir às travestis com pronomes de tratamento femininos. A travesti não é um homem que se "traveste" de mulher, essa é uma prática de cross-dressers, por exemplo. A travesti também passa por alterações em seu corpo, colocando silicone, por exemplo. Como a maioria não tem condições de realizar os procedimentos cirúrgicos adequados, as bombadeiras 6 colocam silicone industrial em seus corpos para terem seios e nádegas femininas. A maioria encontra nas ruas (e nos desejos de homens cisgêneros) uma forma de sobreviver: a prostituição. Afinal, infelizmente a marginalização começa no ambiente privado: a expulsão de casa e da família. Essas identidades vulneráveis lutam pelo reconhecimento e pela inteligibilidade dessa corporeidade feminina considerada abjeta e subalterna, justamente por haver diferenças corporais em relação às mulheres cisgêneras (apesar de que, quantas mulheres cisgêneras hoje não fazem o pacto com a medicina ao colocarem silicones e depois continuar uma manutenção?).

É importante ressaltar que pessoas transexuais reivindicam o reconhecimento de sua identidade como homem ou como mulher. Travestis se identificam como travestis, ou seja, não são homens nem mu-

6 Bombadeiras são mulheres que aplicam o silicone industrial no corpo de travestis e transexuais.
Iheres. Nesse trabalho, inclusive, o termo "pessoas trans" será usado para se referir a pessoas transexuais e travestis. Essas posições identitárias não vão contra parte do marco teórico trabalhado, pois Butler (2015) já tem afirmado que não se pode negar e desrespeitar a forma como pessoas trans se identificam. Isso significa que o gênero não é sempre fluído e volátil, como pode parecer ${ }^{7}$.

Ao mesmo tempo, usaremos a compreensão de Butler de que alguns corpos são considerados abjetos. Um corpo é considerado abjeto pelos sujeitos que descartam elementos estranhos de suas identidades. As fronteiras do corpo do Eu são estabelecidas pelo o que "não é Eu" (Butler, 2014, p. 191). o corpo abjeto não é assim por natureza, mas lido como desprezível e descartável (Mello, 2012). O processo de exclusão do próprio corpo significa a diferenciação entre o "meu" e o "do outro" e essa "operação da repulsa pode consolidar 'identidades' baseadas na instituição do 'Outro', ou de um conjunto de Outros, por meio da exclusão e da dominação [...] para fins de regulação e controles sociais" (Butler, 2014, p. 191). A exclusão marca o lugar do que é considerado ser e aquele que é "não-ser", delimitando forçosamente uma inteligibilidade que atravessa leis, o saber e a verdade $^{8}$. Butler ainda explica que o abjeto designa uma identidade, um lócus do sujeito que é inabitável, pois a identificação àquele lugar é temida e rechaçada socialmente, por isso "o domínio do sujeito circunscreverá sua própria reivindicação de direito à autonomia e à vida" e "o sujeito é constituído através da força da exclusão e da abjeção, uma força que pro-

7 Essa posição é posta em outro artigo (Flores; Dias; Brum, 2017) que afirma que a jurisprudência do Tribunal de Justiça do Estado do Rio Grande do Sul se fecha no binarismo de gênero, sob o pressuposto de que identidades são "performáticas" e "flexíveis". Como se verá no presente artigo, as lutas de pessoas trans levam a outra compreensão: o processo de identificação é diferente para as pessoas, podendo manter ou não a coerência heteronormativa; identidade não se confunde com identificação, a qual acontece como processo durante a vida e pode resultar ou não no posicionamento de uma pessoa com uma identidade fixa; transexuais se identificam dentro do binarismo homem/mulher; e travestis se identificam como travestis, o que rompe com o binarismo, mas também se sustenta como uma identidade própria.

8 No artigo, Butler faz uma análise filosófica de um caso real em que o corpo de uma criança é atravessado por diversos discursos da intersexualidade e da transexualidade até o ponto em que se coloca sobre si mesmo, se autodeterminando homem (Butler, 2001). 
duz um exterior constitutivo relativamente ao sujeito, um exterior abjeto que está, afinal, 'dentro' do sujeito, como seu próprio e fundante repúdio” (Butler, 2000, p. 112). O abjeto se encontra ligado ao repúdio, na medida em que precisa repudiar algo para preservar sua clausura como forma de defesa contra aquilo que ameaça sua estabilidade e sua sobrevivência (Sabsay, 2008, p. 216). A travesti e as pessoas transexuais são abjetas até certo ponto para pessoas cisgêneras justamente para que esses tentem manter um sistema padrão de corpos coesos e coerentes.

De acordo com Jorge Leite Junior (2012), há uma alteração na concepção abjeta de uma identidade quando ela tem suas características organizadas em uma categoria. Essa domesticação do abjeto passa a ser um "monstro", que vive nos limites do saber, do humano, do mundo. No caso de travestis e transexuais, suas identidades foram patologizadas no século $\mathrm{XX}$, quando buscavam o "verdadeiro sexo", e estigmatizadas como anormais. Essa nova inteligibilidade pressupôs uma legitimação da violência contra elas (Leite Junior, 2012). Isso é evidente em narrativas de pessoas transexuais e travestis, pois assim afirma Sofia Favero (2014): “o ódio a quem quebra o padrão de gênero é tão grande, as pessoas se sentem tão ofendidas com quem não segue suas regras divinas, que a violência é a primeira resposta que conseguem atribuir". Apesar, portanto, de haver inteligibilidade da identidade transexual, é importante compreender como e se ela tem mecanismos de reconhecimento. Se por um lado podem-se construir limites para a inteligibilidade, esses limites excluem aquilo que the é abjeto, irreconhecível. Na transfobia, o cisgênero é colocado como regra (cisgenerismo) e o que não é possível dentro dessas normas é excluído.

Transfobia é o medo ou aversão a pessoas transexuais, travestis e transgêneros, e ela tem dimensões diferentes. Legalmente não há reconhecimento positivado de identidades não-cisgêneras, além de resoluções do Conselho Federal de Medicina. Na medicina, a pessoa transexual é considerada mentalmente transtornada, sendo que no CID se tem o transtorno de identidade de gênero/transexualismo e no DSM, a "disforia de gênero". Ademais, a identidade travesti aparece no CID como Travestismo Bivalente, caracterizada como um estado temporário, sem a vontade de realização de cirurgias e a "mudança de vestimentas" não "acompanha" a excitação sexual. Não obstante, como já exposto, a travesti vai além desse padrão: ela mantém seus prazeres corporais sem cirurgias e faz modificações no corpo para feminilizá-lo.

Socialmente, a maioria das mulheres transexuais e travestis têm lugar e horário marcado: a rua à noite. Por muitas trabalharem como prostitutas, estão sujeitas a vulnerabilidades de saúde e segurança. Essa territorialização dos corpos transgêneros é mantida como forma de escamotear suas subjetividades e de mantê-las afastadas do exercício de cidadania plena. Esse é o reflexo do saber-poder do discurso cisgênero, no qual o lugar da abjeção é reiterado cada vez que as identidades de transexuais e de travestis são invisibilizadas e não são representadas nos discursos como sujeitos de direito. Ocorre, portanto, uma exclusão estrutural, com dificuldades em se manter nos ambientes escolares, de alcançar um trabalho qualificado e até mesmo de utilizar banheiros (Jesus, 2013b, p. 105). Transexuais e travestis morrem excessivamente no Brasil, onde se tem " $40 \%$ dos casos desde janeiro de 2008 , e $42 \%$ dos casos em 2016" no mundo (Transgender Europe, 2016). Os casos de transfobia aparecem de diversas formas no cotidiano:

Para conseguir o uso do nome social na faculdade é uma guerra. Como se não tivéssemos o direito de usar nossos nomes em todos os ambientes. Para mim, o Estado é o maior inimigo da comunidade trans. [...] Ser trans não faz com que ninguém cometa suicídio. A transfobia e a falta de inclusão, sim, faz (Damico, 2016).

O direito, de alguma forma, tem papel na construção das possibilidades para a vida de pessoas transgêneras. Uma das questões é o nome, possível de mudança apenas juridicamente. A alteração do nome é elemento que compõe a autonomia do sujeito de narrar a si mesmo como se identifica. O nome simboliza no discurso a chamada do sujeito e de seu corpo. Se seu nome está em dissonância com sua identidade, ocorre um constrangimento e uma violência contra si mesmo. Ninguém quer ser chamado por um nome com o qual não se identifica nem ser discriminado pela incoerência entre nome civil e identidade: 
Uma vez eu fui procurar trabalho com uma mulher cis em uma loja de cosmético. O rapaz que atendeu a gente disse que havia duas vagas e que a gente se encaixava no padrão que eles procuravam. Aí, quando eu entrego o currículo, o assunto muda na hora. Ele vira para a minha amiga e fala: "A sua vaga é mais garantida, né, pelo seu currículo". E vira para mim: "Você vai precisar esperar para uma próxima, porque eu vi agora que só temos uma vaga". Ou seja, tinha duas vagas até ele saber o meu nome civil... (Dominik, 2015)

\section{Dogmática jurídica: o nome é direito cisgênero?}

"Eu quero é que as pessoas saibam que eu sou transexual, pois quero que a minha cidadania e de outras muIheres como eu sejam garantidas" (Moraes, 2015). É por conta de reivindicações como essa que o Judiciário brasileiro foi, nas últimas duas décadas, permitindo a mudança do prenome e do sexo no registro civil. Parte dessa mudança também foi no imaginário jurídico, que pode ser percebido na dogmática atual. 0 direito ao nome, como se verá, está atrelado ao corpo, portanto, às modificações feitas nele em razão da identidade de gênero da pessoa. Um direito está atrelado ao outro pela própria materialidade dos corpos transgêneros.

Luiz Edson Fachin aponta com muita propriedade o direito fundamental ao corpo, que é embasado em um contexto constitucional que preza pela liberdade e autonomia do sujeito (Fachin, 2014, p. 42). A autonomia, em concepção posterior à "autonomia da vontade" da visão liberal, está ligada à dignidade da pessoa e também aos limites propostos no ordenamento jurídico, que não são normas morais nem religiosas (Fachin, 2014, p. 43). Por exemplo, a liberdade religiosa tem seus próprios limites e não pode atingir o direito de autonomia em relação ao gênero, porquanto tem seu conteúdo negativo (restrições aos outros) e positivo (possibilidades de usufruir a liberdade) (Weingartner Neto, 2013). Como a liberdade religiosa é do indivíduo (e ele é quem usufrui de sua consciência conforme sua autonomia), não há qualquer previsão de liberdade de interferência religiosa sobre o corpo do outro. Infelizmente essa compreensão da dogmática ainda não alcança a realidade, já que:
A gente fala sobre a autonomia dos corpos, mas desde que certas pessoas não façam algo em seus corpos. Ou seja, a autonomia vai até determinado limite e até as pessoas que lutam por direitos se limitam em determinado campo. (Siqueira, 2016)

Percebe-se que o corpo está em disputa. Afinal, o corpo "cumpre uma função social importante na conformação de uma identidade do sujeito e mesma de sua própria felicidade" (Fachin, 2014, p. 43), até por ser a materialidade do sujeito e a sua projeção física (Gagliano; Pamplona Filho, 2016, p. 217). A identidade de travestis e transexuais não se destaca de seus corpos vistos com nossos olhos sensíveis. É materialmente visível a identidade através do corpo da pessoa: travestis e transexuais fazem alterações, tais como no cabelo, nos seios e nas nádegas.

O direito ao corpo tem seus limites propostos no art. 13 , os quais repercutiram na discussão da possibilidade de realizar cirurgias de transgenitalização. A conclusão foi a garantia da cirurgia, como foi definido na Resolução CFM n ${ }^{\circ} 1.682 / 2002$, hoje revogada pela Resolução CFM $n^{\circ} 1.955 / 2010$. Os limites do artigo são a diminuição permanente da integridade física, os bons costumes e a finalidade terapêutica, sendo que o terceiro critério é hierarquicamente superior. Esse elemento é o que salvaguarda a transgenitalização, porquanto ela proporciona o direito à saúde com a readequação do corpo à identidade do sujeito (Tepedino; Barboza, 2007, p. 37-38).

Atender ao critério geral dos bons costumes é um processo que leva em consideração a sociedade livre, justa e plural, na qual os costumes são tão diversos quanto as culturas, o que foi recepcionado com o Estado Democrático de Direito ao adotar a lei positiva e não a lei natural (o que implica também em não optar por uma moral única). Nesse sentido, o que pode ser entendido como bom costume para pessoas cisgêneras (a manutenção de coerência do gênero com o corpo e o "sexo"), não é o mesmo para transexuais e travestis que realizam intervenções corporais a fim de se adequarem às imagens corporais com as quais se identificam.

A dogmática jurídica tem revisto a indisponibilidade do próprio corpo ao levar em consideração a digni- 
dade da pessoa humana, a diferença e a diversidade moral. Bittar (2015) afirma que a cultura dos direitos humanos tem trazido o reconhecimento à liberdade de orientação sexual e que as pessoas não devem ser cerceadas em sua expressão, por isso não cabe ao Estado regular o sujeito psicofisicamente, mas sim "salvaguardar a proteção, a retidão e os cuidados de saúde necessários” (Bittar, 2015, p. 137) para que a readequação corporal seja bem sucedida.

Na mesma esteira de Bittar, Pablo Stolze e Rodolfo Pamplona (Gagliano; Pamplona Filho, 2016, p. 220), Cristiano Chaves e Nelson Rosenvald (Farias; Rosenvald, 2016, p. 227) ${ }^{9}$ afirmam que o dispositivo em questão não vai contra os "bons costumes", nem impede a cirurgia de transgenitalização em função da dignidade da pessoa humana, haja vista ser uma prática terapêutica que condiz com os "casos de transexualismo". No âmbito do Direito Civil, o alcance do art. 13 também foi confirmado no enunciado 276 da IV Jornada de Direito Civil $^{10}$ no que tange àqueles (as) que desejam a transgenitalização, garantida a consequente mudança do prenome e do sexo no Registro Civil.

A cirurgia que altera a genitália, contudo, não é almejada por todas as travestis e transexuais ou não é tão facilmente alcançada. Uma parcela delas repudia seus órgãos genitais, enquanto outra continua se identificando com seus caracteres sexuais primários. O trabalho de Berenice Bento demonstra que nem todas as pessoas transexuais rejeitam completamente seus corpos, em especial, a genitália nem sempre é abjeta para uma pessoa transexual (Bento, 2006).

A própria definição psiquiátrica da disforia de gênero e do transexualismo não alcança essas pessoas, por-

9 Os autores optam por utilizar o vocabulário psiquiátrico, estereótipo da transexualidade como doença e também insistiram em tratar travestis no masculino, até mesmo afirmando que as travestis usam seu corpo duplamente, "diferente de pessoas transexuais”. Como já visto, há pessoas transexuais que não necessitam de cirurgia transgenitalizadora e isso não as descaracteriza como transexuais, pois a própria pessoa define sua identidade, não uma categoria médica.

100 art. 13 do Código Civil, ao permitir a disposição do próprio corpo por exigência médica, autoriza as cirurgias de transgenitalização, em conformidade com os procedimentos estabelecidos pelo Conselho Federal de Medicina, e a conseqüente alteração do prenome e do sexo no Registro Civil. quanto eles preveem uma pessoa transexual binária, ou homem ou mulher, com pênis ou vagina, de acordo com a coerência de gênero. Esses corpos transexuais e travestis, portanto, deveriam estar totalmente de acordo com a regra heteronormativa por causa de uma definição feita por cisgêneros? Esses corpos existentes já fornecem a seguinte resposta: não, afinal "somos pessoas como qualquer outra. Temos sentimentos, temos sonhos, sofremos... Eu sempre pergunto: 'O que muda na sua vida eu ser trans?'. Eu acho que ninguém é obrigado a gostar de trans, mas tem que respeitar" (Dominik, 2015). Seu conforto, sua identidade, sua privacidade, seus desejos, todos se encontram amparados constitucionalmente e também pelo direito à integridade psíquica, o qual "se destina a preservar o conjunto psicoafetivo e pensante na estrutura humana" que se completa com o direito ao corpo e a defesa integral da personalidade humana. Ademais, "procura esse direito resguardar os componentes identificadores da estrutura interna da pessoa e norteadores de sua própria ação (elementos de sua mente)" (Bittar, 2015, p. 182).

No caso das mulheres transexuais e das travestis que não querem ou não podem realizar a transgenitalização, ou dos homens trans que têm suas cirurgias ainda em caráter experimental no Brasil (e que não podem ser realizadas em hospitais privados ainda), eles devem ser esterilizados e terem seus genitais modificados a fim de corresponderem à coerência de gênero? Poucos hospitais públicos estão habilitados para realizar a cirurgia em mulheres transexuais e as filas de espera já são contadas em anos (hoje os hospitais universitários habilitados são da USP, UERJ, UFG, UFRGS e UFPE).

O paciente tem sua autonomia e dignidade resguardadas pelo art. 15 do Código $\mathrm{Civil}^{11}$, qualquer procedimento deve ser realizado com o livre esclarecimento sobre suas implicações. Uma pessoa que não tem condições de realizar a cirurgia não pode ter esta como premissa para ter sua identidade e sua dignidade reconhecidas pelo Estado, porquanto o fato da cirurgia não está atrelado legalmente ao direito de ser reconhecido.

11 Art. 15: Ninguém pode ser constrangido a submeter-se, com risco de vida, a tratamento médico ou intervenção cirúrgica. 
Há, no mínimo, dois tipos de opressões às pessoas transexuais e travestis: "não permitir que o indivíduo modifique seu corpo para se adaptar a sua identidade de gênero" e "determinar que o transexual realize a cirurgia de redesignação sexual para que só então possa ter sua identidade de gênero reconhecida" (Fachin, 2014, p. 49). Nome e corpo estão conectados de todas as maneiras na materialidade, mas ainda resta a discussão sobre a conexão entre as modificações corporais e o reconhecimento civil de sujeitos transgêneros.

O nome é elemento designativo da identidade que é simbolizado entre o público e o privado, o indivíduo e a sociedade. Tem duas funções precípuas: identificação da pessoa e evitar confusão com outra (Bittar, 2015. p. 195). No caso, o art. 16 elenca o direito ao nome e o bem jurídico tutelado é a identidade. Carlos Roberto Gonçalves (2016, p. 149) sustenta que o nome é individualizador e que tem um aspecto público, que decorre da necessidade do Estado da identificação do indivíduo por um nome inalterável, ressalvadas as hipóteses admitidas, e o aspecto individual, que compreende no uso, na defesa contra usurpação de direito autoral e contra exposição ao ridículo.

Bittar (2015, p. 200) afirma que no caso de pessoas transexuais a identidade fica afetada quando há incongruência entre nome civil e identidade, o que pode ser resolvido com o disposto no art. 58 da Lei n. 6.015/1973, que permite substituir o prenome por apelido público notório. 0 nome já foi considerado imutável em redação antiga do art. 58. Após a Lei $\mathrm{n}$. 9.708/1998, alterando o art. 58, o nome passou a ser considerado definitivo, haja vista que a própria lei reconhece possibilidades de retificações. A retificação do nome por um apelido é, na verdade, pelo nome adotado pelo indivíduo, com o qual verdadeiramente se identifica e reflete seu gênero.

O parágrafo único do art. 55 da Lei de Registros Públicos informa que os nomes registrados não podem expor as pessoas ao ridículo. Pessoas transexuais vão se identificando com outro gênero ao crescerem, dessa forma, o nome é um devir que se desconecta de sua identidade, e que passa a expô-las a constrangimentos quando há incoerência entre o que é visto no corpo e no documento de identidade formal. Tal dispositivo deve ser lido sob essa hermenêutica com interpretação extensiva, na qual é levada em consideração a impossibilidade de o sujeito ter autonomia total sobre sua identidade em seus primeiros anos de vida, principalmente no que tange à compreensão das relações entre o Estado, sua família e seu corpo. O nome, portanto, é mutável e é moldável de acordo com seu gênero. Sem a modificação do prenome, há discordância entre o corpo que é visto e a identidade civil que é lida. Esse descompasso é materializado em constrangimento, humilhação, discriminação e execração pública (Fachin, 2014, p. 50).

A dogmática também tem compreendido que a mudança do sexo (estado sexual) no registro civil é possível (Farias; Rosenvald, 2016, p. 300). Não obstante, ainda permanece a pergunta: podem o/a transexual e a travesti requerer a retificação do registro civil do sexo sem realizar a cirurgia de transgenitalização? Luiz Edson Fachin (2014, p. 51) responde precisamente à pergunta sobre transexuais: o direito à mudança do "sexo" no registro civil é amparado constitucionalmente pela dignidade da pessoa humana e pela solidariedade social, porquanto, sem a alteração, a pessoa transexual continuará sofrendo a constrição do estigma e da discriminação social. A travesti é incluída nessa percepção? Afinal, a dogmática tem se reportado às pessoas transexuais, não de forma ampla a pessoas trans, e sem especificar as travestis como sujeitos de direitos que podem pleitear essa demanda judicialmente.

Gonçalves (2016, p. 169) apregoa que nos casos de transexualidade, os Tribunais têm compreendido que o prenome pode ser alterado, até em casos mesmo sem a realização da cirurgia, já que ela pode ser "constatada em avaliação psiquiátrica, uma vez que se trata de um transtorno mental". Apesar de o autor sustentar devidamente a alteração do sexo no registro civil, ele ainda apoia o estigma patológico e mais adiante, na mesma página, também sustenta que a diferença com a travesti é que a pessoa transexual "acredita firmemente pertencer ao outro sexo", descartando o conhecimento sobre gênero, colocando a identidade como crença sobre si mesmo.

Nas doutrinas foi possível perceber o apontamento para a dignidade humana, que também será de relevância para a continuação desse estudo. Em linhas gerais, a dignidade da pessoa humana foi reconheci- 
da sob a égide da ideia de que o Estado é "que existe em função da pessoa, não o contrário" (Sarlet, 2013, p. 124). Juridicamente, a dignidade tem um conteúdo ético, é uma norma jurídico-positiva e valor fundamental para a ordem jurídica, especialmente no que tange a efetivação de direitos fundamentais. Tal valor só faz sentido e é posto por causa da intersubjetividade: como a comunidade e o sujeito se relacionam sobre o valor atribuído à pessoa e seus direitos e deveres. O Estado, portanto, tem duas funções sobre a dignidade da pessoa humana: defender (negativa) e promover o respeito (positiva) (Sarlet, 2013, p. 124-125).

\section{$5 \quad$ Dados da jurisprudência}

Nessa seção a jurisprudência apresentada será composta por ementas de acórdãos do Tribunal de Justiça de São Paulo encontradas em seu site, na pesquisa de jurisprudência (todos os números de processos citados podem ser encontrados no referido site). A palavra-chave utilizada foi "transexual" e o resultado foi filtrado pelos assuntos "registro de nome" e "registro de sexo". Não foram encontrados julgados de retificação de registro civil de travestis. Foram encontradas 50 ementas referentes à retificação de registro civil de pessoas transexuais, após a exclusão daque- les referentes ao conflito de competência. O intervalo temporal encontrado foi entre 2009 e 2016.

Antes de apresentar os resultados da pesquisa jurisprudencial sobre a alteração de registro de pessoas transexuais, é importante ressaltar que foi feita uma pesquisa com o termo "travesti" e depois foram adicionados dois termos mais frequentes, sejam eles "Criminal" e "Penal" (que são indicados pelo próprio sistema de busca). No primeiro momento foram encontrados 814 documentos e após o filtro apareceram 686 decisões. Estudar esse fato não é objetivo desse artigo, mas essa breve pesquisa demonstra que a identidade travesti aparece em processos penais ao mesmo tempo em que não aparece nas decisões de retificação de nome de registro civil. Isso nos indica que essa identidade não está sendo observada e nomeada no que tange o reconhecimento jurídico civil nos processos em que foi necessário recorrer à segunda instância.

Tendo em vista esse percurso, a amostra de decisões encontradas sobre a retificação de registro de pessoas transexuais foi sistematizada. A análise após a amostragem recolhida resultou nas seguintes categorias (o número em parênteses representa o número de ementas agrupadas em cada categoria):

\begin{tabular}{|c|c|c|}
\hline Categorias & $\begin{array}{l}\text { Qtd. de } \\
\text { processos }\end{array}$ & Número dos processos \\
\hline \multicolumn{3}{|l|}{ I. Alteração do nome e do sexo } \\
\hline i) alteração do nome apenas, sem citar sexo & 3 & $\begin{array}{l}0007607-12.2010 .8 .26 .0100 ; 0018633-80.2012 .8 .26 .0344 ; \\
0025401-94.2006 .8 .26 .0000\end{array}$ \\
\hline ii) alteração do nome sem cirurgia & 6 & $\begin{array}{l}\text { 1002028-41.2014.8.26.0451; 0001360-69.2014.8.26.0457; } \\
\text { 0055269-67.2008.8.26.0576; 0013934-31.2011.8.26.0037; } \\
\text { 0082646-81.2011.8.26.0002; 0008087-39.2011.8.26.0428. }\end{array}$ \\
\hline iii) alteração apenas do sexo & 6 & $\begin{array}{l}\text { 1074167-11.2013.8.26.0100; 1102067-95.2015.8.26.0100; } \\
\text { 1034767-25.2015.8.26.0001; 1027203-86.2015.8.26.0100; } \\
\text { 0627715-81.2008.8.26.0100; 0015957-43.2010.8.26.0664. }\end{array}$ \\
\hline $\begin{array}{l}\text { iv) alteração de nome e sexo reconhecidas (com cirurgia } \\
\text { feita) }\end{array}$ & 3 & $\begin{array}{l}\text { 0004782-12.2011.8.26.0084; 9282226-47.2008.8.26.0000; } \\
\text { 9069885-07.2007.8.26.0000. }\end{array}$ \\
\hline v) alteração de nome e sexo (sem cirurgia) & 2 & 0030254-05.2007.8.26.0068; 0008539-56.2004.8.26.0505. \\
\hline $\begin{array}{l}\text { vi) retificação do nome e do sexo com alterações inscri- } \\
\text { tas à margem do livro de registro de nascimento }\end{array}$ & 3 & $\begin{array}{l}0003025-02.2008 .8 .26 .0047 ; 0627715-81.2008 .8 .26 .0100 \\
0007869-83.2009 .8 .26 .0168\end{array}$ \\
\hline $\begin{array}{l}\text { vii) retificação do nome e do sexo sem alterações inscri- } \\
\text { tas à margem do livro de registro de nascimento }\end{array}$ & 1 & 0013923-23.2008.8.26.0161. \\
\hline
\end{tabular}




\begin{tabular}{|c|c|c|}
\hline i) provimento da ação de retificação & 6 & $\begin{array}{l}0005436-85.2012 .8 .26 .0238 ; 0062067-91.2012 .8 .26 .0224 ; \\
1022947-37.2014 .8 .26 .0100 ; 0040698-94.2012 .8 .26 .0562 ; \\
0033254-70.2009 .8 .26 .0576 ; 9000677-96.2009 .8 .26 .0506\end{array}$ \\
\hline $\begin{array}{l}\text { ii) improvimento de retificação do nome, por não ter } \\
\text { feito cirurgia, falta de interesse do autor }\end{array}$ & 13 & $\begin{array}{l}\text { 0003616-51.2012.8.26.0587; 0019307-41.2012.8.26.0576; } \\
\text { 0025917-51.2013.8.26.0071; 0908847-35.2012.8.26.0037; } \\
\text { 0023241-58.2011.8.26.0344; 0031545-57.2011.8.26.0114; } \\
\text { 0004782-12.2011.8.26.0084; 9000677-96.2009.8.26.0506; } \\
\text { 0003330-67.2011.8.26.0568; 0033051-03.2006.8.26.0451; } \\
\text { 9070337-22.2004.8.26.0000; 0003073-19.2009.8.26.0663; } \\
9100784-17.2009 .8 .26 .0000\end{array}$ \\
\hline $\begin{array}{l}\text { iii) caso de obrigação de passar por equipe multidisci- } \\
\text { plinar }\end{array}$ & 3 & $\begin{array}{l}\text { 2174242-79.2015.8.26.0000; } 2117660-59.2015 .8 .26 .0000 \\
0049484-11.2011 .8 .26 .0224 \text {. }\end{array}$ \\
\hline $\begin{array}{l}\text { iv) caso de desobrigação de diagnóstico e produção de } \\
\text { prova oral }\end{array}$ & 3 & $\begin{array}{l}2207613-34.2015 .8 .26 .0000 ; 2145616-50.2015 .8 .26 .0000 \\
2083427-36.2015 .8 .26 .0000 \text {; }\end{array}$ \\
\hline v) dispensa de perícia, pois já tem laudo & 1 & $2205957-42.2015 .8 .26 .0000$ \\
\hline
\end{tabular}

Essa amostragem permite diversas inferências empíricas da diversidade de entendimentos do Tribunal.

Primeiramente, os julgamentos de apelação revelam a medida de reconhecimento da identidade transexual como passível e legítima de ter seu nome alterado em função de sua condição. Treze decisões encontradas indeferiram a retificação do registro civil e trinta e sete deferiram ${ }^{12}$. No Gráfico 1 é possível perceber como elas se distribuíram ao longo dos anos.

O Tribunal de Justiça de São Paulo, no geral, tem aceitado a ação de retificação de registro civil de pes- soas transexuais, porquanto a maior parte dos julgados foi de provimento das demandas. No ano de 2016 não houve nenhuma decisão em sede de recurso desfavorável a pessoas transexuais, o que estava sendo anunciado com a queda após 2012, de cinco improvimentos, para uma variação entre um e dois entre 2013 e 2015. 0 entendimento majoritário desse Tribunal tem sido em favor do reconhecimento da retificação do registro civil.

Os principais argumentos levantados em favor das retificações têm sido a dignidade da pessoa humana (foi citada em doze julgados) e o constrangimento

Gráfico 1 - Número de provimentos e improvimentos de ações de retificação entre 2009 e 2016.

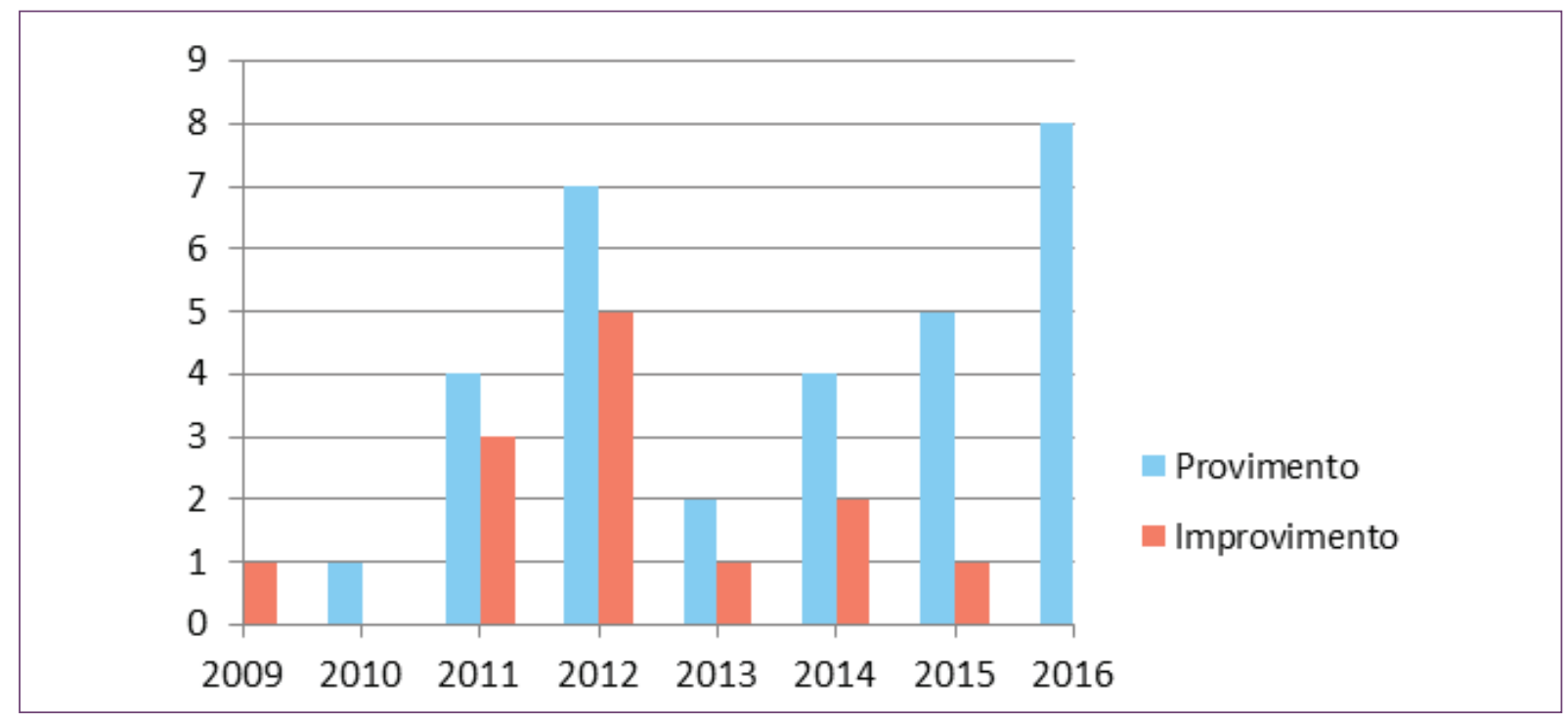

12 As ementas que representam o deferimento são dos itens $1 . i$ a 2.i, e um caso do item 2.iii. 
pelo qual as pessoas passam com a incoerência entre nome e identidade visual (o constrangimento foi citado em onze dos julgados). Vale ressaltar a inovação de uma ementa que citou os princípios de Yogyakarta para reconhecer a retificação ${ }^{13}$. Os princípios de Yogyakarta são parte de uma interpretação feita por uma comissão internacional de juristas sobre os direitos humanos em função do gênero e da sexualidade (Comissão Internacional de Juristas; Serviço Internacional pelos Direitos Humanos).

Assinala-se que oito dessas decisões demonstram a desnecessidade da cirurgia de transgenitalização para a retificação, sendo que houve alteração do nome sem cirurgia, duas com alteração de nome e sexo (sem cirurgia) e uma em que se reconheceu a retificação do sexo (sem prévia cirurgia).

Apesar da maioria dessas decisões serem referentes à retificação do nome, há a tendência da dissociação da cirurgia transgenitalizadora como requisito para a retificação do sexo, porquanto o gênero da pessoa tem sido levado mais em consideração em função da desconformidade entre o sexo biológico e o comportamento social do indivíduo. A cirurgia se revela, portanto, aspecto secundário frente à forma como a pessoa se identifica. Foi possível encontrar uma relação feita pelo magistrado entre o direito à alteração do nome na Lei de Registros Públicos e a disposição do próprio corpo, que afirmou que a imposição da cirurgia "significaria a instituição de requisito discriminatório, a forçar indivíduos a realizar interferências cirúrgicas no próprio corpo, nem sempre desejadas"14.

Não obstante, há também aqueles que não fizeram a cirurgia e querem realizá-la. 0 apontamento desse fato em decisões demonstra que é considerado importante que a pessoa queira se submeter a essa modificação corporal. Esse desejo serve, portanto, como indício de que a pessoa é transexual. Ou seja, apesar de não ter feito a cirurgia e se afirmar "não se deve associar gênero à genitália", também aponta que há acompanhamento médico, tratamento hormonal e que está "prestes a passar por procedimento cirúr-

13 Processo n. 0018633-80.2012.8.26.0344. 14 Processo n. 0001360-69.2014.8.26.0457. gico de transgenitalização" ${ }^{15}$. Nessa mesma ementa, um argumento jurídico presente é da possível violação da dignidade humana. Na mesma decisão há o alinhamento de três elementos: a dignidade humana, a não realização da cirurgia e a vontade de fazê-la. 0 apontamento dessa vontade, mesmo que esteja expressa nos autos como prova, revela a intenção do magistrado de pontuar esse fato como importante para seu processo decisório. Foi algo que se quis citar para dar embasamento para uma decisão.

Outro dado importante é a proteção do direito à intimidade das partes autoras na averbação com as alterações inscritas à margem do livro de registro. Há quatro decisões explícitas a favor da inscrição. Em outras duas foi reconhecida a desnecessidade de inscrever a modificação de sexo masculino para feminino (eram casos apenas de transexuais femininas) ${ }^{16}$. Outras também fazem referência, como o exemplo a seguir: "possibilidade de modificação, com anotação no registro de nascimento da alteração - Circunstância que não acarreta constrangimento ao autor"17. A explicitação de que houve uma mudança no registro civil é em função dessa transição da imagem de um corpo. Essa é uma forma de marcar juridicamente as alterações feitas no corpo e no entendimento da pessoa sobre si mesma. Se a pessoa quis, como se fosse uma simples opção, fazer a retificação, que seja possível sua informação para terceiros por meio da anotação no registro.

A alteração do sexo foi possível em oito ementas ${ }^{18}$; a cirurgia foi dispensada como critério em sete ementas ${ }^{19}$; e apenas duas indicam a retificação do nome e do sexo sem alterações inscritas à margem do livro de registro de nascimento ${ }^{20}$. A palavra "transexualismo" foi encontrada em dez ementas (20\%) e dezessete delas indicam a necessidade de patologização como requisito para a retificação do registro civil $(34 \%)^{21}$. Mesmo que não seja o ponto mais relevante em algumas decisões, percebe-se que existe uma relevância do laudo "atestando o quadro

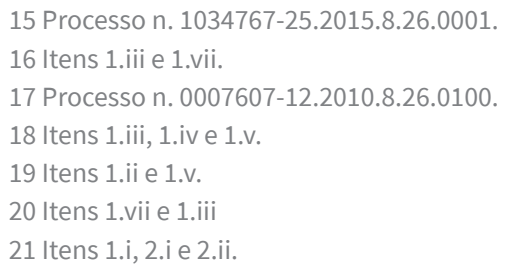


de disforia de gênero (302.85), com transtorno de identidade sexual (CID-10: F64.1)"22.

Por serem decisões judiciais, que se constroem por meio das provas e da concatenação de um jurista, ficou patente a necessidade delas para a constituição da pessoa transexual como sujeito de direito. Assim, a instrução do processo chega a ser afirmada em uma das ementas: "Possibilidade de o requerente demonstrar sua inclinação sexual, bem como a existência de transtorno de identidade de gênero. Necessária instrução"23. Em outra situação, também foi necessário que se juntassem provas da aparência física - é, inclusive, comum que a instrução tenha fotos do (a) requerente -, mas isso foi atestado pelo relator: "Nome atual que, em face da condição atual do apelante, o expõe ao ridículo. Requerimento de provas que demonstrem, verdadeiramente, que a aparência do autor é de uma mulher"24. Ressalta-se o uso da ideia de "verdade" como forma de legitimar o requerimento de provas sobre o sujeito e é necessária uma imagem para se demonstrar quem se é. Ao mesmo tempo, tal enunciado tem uma incoerência de linguagem quando se refere à requerente como "o autor" e em seguida afirma que a prova é sobre ser uma mulher.

Seguindo essa trilha, outro fator importante que aparece nas decisões é o pronome de tratamento usado para os (as) requerentes. Na maioria das vezes, são chamados de acordo com o gênero do nome civil, não com o nome novo, mesmo quando se trata de deferimento. O oposto ocorre da seguinte forma: "Feminilidade evidente da autora, que se comporta e se apresenta como mulher, desde tenra idade, para seu círculo familiar e de amigos, bem como para a sociedade." 25 ou "Apela a autora sustentando que sofre situações vexatórias" 26 .

Até em caso em que o nome foi alterado do masculino para o feminino, o julgador se refere à requerente no masculino quando decide pela retificação do sexo no registro civil: "Evidente, ainda, o constrangimento daquele que possui o prenome [...], mas que consta no mesmo registro como sendo do sexo masculino"27.

Outro dado pertinente de ser analisado é o da alta taxa de improvimento por falta de interesse processual. Se o interesse é requisito para a ação que indica que o sujeito quer e pode conseguir alcançar o bem jurídico tutelado, o número alto demonstra que há um pensamento dos magistrados no sentido de que esse pleito não seria juridicamente viável. Haveria falta de interesse processual principalmente daquelas mulheres transexuais que não realizaram a cirurgia de redesignação sexual, pois "não bastam apenas mudanças na aparência, é necessária a completa transformação, através de procedimento cirúrgico para a certeza da orientação sexual"28. Em 2014 também houve acórdão nesse sentido, que criava a cirurgia como requisito e afirmava que não havia interesse de agir porque os registros públicos "têm caráter de definitividade, espelhando a realidade"29.

Além disso, há os casos também em que se exige que o sujeito passe por uma equipe multidisciplinar que avalia e comprova a transexualidade da pessoa. Em decisão de 2016 é possível ainda ver esse posicionamento: "Alegação do agravante de que a comprovação da transexualidade por meio de laudo médico é desnecessária, abusiva e ofensiva - Decisão mantida - Necessidade de se verificar a desconformidade entre o sexo biológico e o psicológico do agravante por meio de equipe multidisciplinar" ${ }^{\prime 3}$.

\section{Discussão: os limites criados pelo direito}

O foco, nesse momento, será nas pessoas trans e em como elas são discursivamente produzidas dentro da linguagem jurídica, ou de outra forma, como essa linguagem elabora decisões com base em características de pessoas trans. Não existem ementas referentes a travestis, o que também significa algo. Essa diferenciação entre travestis e transexuais nesse contexto de retificação do registro civil demonstra que apenas pessoas transexuais podem ser autorizadas a ter seu

27 Processo n. 0627715-81.2008.8.26.0100.

28 Processo n. 0003616-51.2012.8.26.0587.

29 Processo n. 0025917-51.2013.8.26.0071.

30 Processo n. 2174242-79.2015.8.26.0000. 
nome e sexo de acordo com a sua identidade de gênero. Travestis, que não se alinham identitariamente às conformidades entre corpo, sexo e gênero, não são passíveis desse reconhecimento jurídico. Já pessoas transexuais, que se identificam como homens ou mulheres, ou seja, se reconhecem nessas categorias (assim como homens e mulheres cisgêneros também se reconhecem), são aquelas possíveis de serem compreendidas pelo sistema jurídico. Não descarto a hipótese e possibilidade de pessoas que se identificam como travestis passarem pelo processo transexualizador e se dizerem transexuais para conseguirem essa autorização. Destaco o fato de que o sistema restringe as possibilidades de inteligibilidade de sujeitos de acordo com um padrão heteronormativo (principalmente a coerência sexo/gênero/desejos/prazeres). Ainda sublinho mais claramente a transfobia, que abrange outras pessoas transgêneras, como travestis, que não se identificam nem como homem nem como mulher. São corpos que escancaram a construção de uma rede normativa (para além do Direito) que exclui pessoas por não estarem de acordo com a previsão social. São corpos que denunciam que a normalização tem suas falhas e que o gênero é impossível de se realizar completamente em seu ideal. Em meio a isso, travestis não são inteligíveis como uma identidade de nome feminino e são excluídas da possibilidade de alteração de nome. Essa é uma forma de compartilhar a abjeção às travestis no discurso jurídico.

As pessoas transexuais também são percebidas de uma maneira específica em boa parte das decisões. A patologização de suas identidades, a atenção para a vontade da cirurgia de redesignação sexual e a inscrição no registro civil da mudança de nome e sexo seriam critérios “legais”. Não são puramente legais, pois se trata de um discurso que se passa como neutro e objetivo por ser jurídico, entretanto há uma normatividade de gênero implícita. A categoria médica e o desejo de alterar as genitálias são, nas decisões, os sinais que os juristas explicitam de que, para eles, o corpo nascido como "macho" realmente é uma muIher. Não ressaltam apenas a identificação e sua vida cotidiana, mas utilizam de um discurso biomédico para justificarem seu entendimento. São as formações discursivas que passam por um conhecimento biomédico que delimitam que aquele corpo não é homem, mas sim uma mulher. Os critérios "legais" são compartilhados de outros sistemas que não o das leis. Não há previsão em textos legislativos sobre esses critérios.

O resultado desse imaginário patologizado é o uso dos artigos de acordo com o primeiro registro civil e a condicionante de inscrever a alteração na retificação. Mesmo que nas decisões os juristas se valham do argumento do perigo da violação da dignidade humana, ainda se referem a uma mulher transexual como "o autor" ou se referem como "transexual", como se fosse a única identidade da pessoa ser transexual (trata-se de uma característica da identidade da pessoa, assim como é o caso de uma pessoa cisgênera). Assim, essa dignidade é reconhecida parcialmente, porquanto não respeitam a própria identidade de gênero, insistindo em se referir à pessoa de acordo com o seu sexo de registro civil (como se ele tivesse definido o gênero da pessoa).

Esse imaginário tem uma pressuposição clara sobre esses corpos: são homens que se sentem mulheres e mulheres que se sentem homens. Não há o entendimento de que esses corpos são significados com um gênero ao nascer, mas que se identificam com outro quando têm capacidade de se comunicar mais claramente. Como pessoas cisgêneras continuam se identificando com o gênero designado ao nascer, pessoas transgêneras são entendidas como aquelas que transitam entre gêneros, que são perturbadas, doentes, e que querem ir contra sua natureza. Essa pressuposição sobre os corpos demonstra um cisgenerismo: a ideia de que todos os sujeitos se identificarão de acordo com o que lhes foi dito desde antes de nascerem ou a ideologia que deslegitima a forma como alguém se identifica sobre seu gênero e seu corpo. Durante a vida de pessoas cisgêneras, poucos são interpelados se são realmente homens ou mulheres e não há uma intervenção jurídica necessária para testar se aquele corpo XY com pênis, que se identifica como homem, realmente é um homem.

A verdade sobre o sujeito é colocada como chave de legitimação do direito da pessoa transgênera. Os enunciados apresentados na seção anterior se referem às provas criadas em juízo ou com discurso biomédico como um atestado de verdade sobre o sujeito. Sua condição corporal é mediada por um outro 
discurso, que não apenas o dos próprios enunciados do sujeito. Sua autonomia é descartada em função de outros autores que falam por si, como se sua autoidentificação não fosse o suficiente. E a verdade está no sexo. Mesmo com laudo psicológico, vê-se que ainda há grande estima dos magistrados pelo desejo de realizar a cirurgia. $O$ desejo de se conformar à expectativa cisgenerista aparece como prova de que a pessoa transgênera pode ser autorizada a mudar de nome.

Pode-se depreender que o significado patologizado e heteronormativo sobre a transexualidade é o fator principal que não permite uma completa efetividade do direito ao nome, pois ainda usam o argumento da coerência total entre o gênero e o sexo, como se fossem dados naturais e que necessariamente devem corresponder às expectativas de padrões rígidos da identidade masculina e da feminina, respectivamente com pênis e vagina. Esses significados que aparecem pelo discurso depreendido das decisões estão presentes na dogmática. Há uma mutualidade entre esses dois campos dentro do direito, porquanto se percebeu em parte da doutrina que as pessoas transexuais são vistas sob a ótica patologizada e que travestis não são incluídas como sujeitos de direito passíveis de reconhecimento civil.

Ao mesmo tempo em que se vê uma porcentagem ainda expressiva de negação do direito ao nome de transexuais, a maioria tem sido a favor da retificação. O ano de 2016 não teve impedimentos na alteração de nome e sexo em segunda instância. Ao mesmo tempo esse dado demonstra que houve empecilhos em primeira instância para a concretização dos direitos dos requerentes.

Em meio a tudo isso, o nome ainda está atrelado à categoria "sexo", utilizada não só como termo biológico, mas também jurídico-político. Tal categoria deixa de ser meramente biológica nesses casos em que juristas não alegam apenas questões cirúrgicas, mas também de dignidade e do registro público. A linguagem jurídica tem sua própria forma de manter e constituir uma identidade, fixando-a de acordo com o primeiro documento legal, sua certidão de nascimento. Momento esse em que apenas outros falam pelo sujeito, como se fossem verdade e como se essa verdade tivesse que ser seguida. Essa necessidade de coerência não é só corporal, esse corpo está no documento e o documento está em seu corpo. A coerência corpo-documento-identidade é de um discurso jurídico que desconsidera a autonomia da pessoa em passar por uma subjetivação outra que não a da cisgeneridade.

Há necessidade da manutenção não só no binarismo para aqueles que não se identificam nem como homem nem como mulher, mas também na particularidade da cisgeneridade, que insiste principalmente na coerência entre o "sexo biológico" e a identidade de gênero, como se fosse realmente uma substância imutável.

Ainda há, portanto, dificuldade na mudança do nome: primeiro, com a necessidade de entrar com processo (custos processuais, advocatícios, de tempo, recolhendo "provas", a espera de dois anos para ter um laudo psiquiátrico e um psicológico etc.); segundo, por depender ainda de critérios adotados pelo juiz sem previsão legal, arbitrariamente, que muito mais estão ligados à percepção sobre a pessoa transexual do que baseado em critérios da lei; terceiro, pela incerteza das decisões, mesmo que o tribunal tenha sido favorável à alteração de nome e sexo. Essa posição favorável tem, como se viu, limites de inteligibilidade, porquanto se baseiam na patologização da identidade trans e nem sempre reconhecem plenamente a pessoa como digna ao se referirem a ela de acordo com seu sexo designado ao nascer.

\section{Considerações finais}

Com o tempo, a dogmática e a jurisprudência têm seguido o mesmo sentido, uma reformulação de significados prévios sobre pessoas transexuais, até porque cada vez mais pessoas trans têm se expressado em movimentos sociais e ganhado uma visibilidade verdadeira na mídia. Tais decisões são muito importantes para quem consegue alterar o nome e o sexo, porquanto isso reduz a possibilidade de constrangimentos ligados ao nome numa seleção de emprego, em instituições públicas e privadas, etc. Ao mesmo tempo, não impede que a transfobia ocorra, já que alguém pode questionar a pessoa se ela "realmente é mulher", por exemplo.

Pessoas trans, com seus corpos, suas lutas e suas sobrevivências diárias, demonstram discursivamente 
a incoerência da heteronormatividade: a falibilidade de suas normas e as fissuras da normatividade de gênero. São normas sociais que, como pudemos ver, reverberam no Direito e nele também são constituídas. Assim, as falhas estão também nele. Nesses casos específicos é possível ver que os argumentos levantados nem sempre estão em concordância com o que se requere, nem com o reconhecimento, nem com o próprio direito (que não previa a redesignação sexual nem a hormonização como requisitos para alteração de registro civil). A dignidade prevista nas decisões nem sempre é completa, assim com o direito ao nome e à retificação de registro civil. O sujeito e seu direito ficam subjugados a outro que decide se autoriza ou não de acordo com seus próprios critérios. Pessoas trans demonstram que o cisgenerismo e o direito são mutuamente falhos, principalmente que o estatuto de neutro e objetivo não se realiza e é uma ficção. A ficção é tanto da normatividade de gênero quanto do discurso jurídico. São fantasias e ilusões sobre o corpo, seus direitos e sua autonomia.

Há uma matriz de inteligibilidade no Direito que limita as possibilidades de pessoas trans serem autorizadas a alterar o nome. Essa é a forma como o senso comum teórico dos juristas atua ao moldar critérios em um processo judicial para dar provimento ou não a um pedido, como se fosse neutro. De certa forma, não há reconhecimento completo, pois se percebe ainda um discurso que não compreende os processos de identificação dos sujeitos e também ainda há uma exclusão de outras identidades, como a travesti. Esse discurso está em dissonância, portanto, com a compreensão de dignidade humana em seu caráter positivo (de proteger os sujeitos) conforme a autonomia de se realizar socialmente de acordo com a forma como se identifica. Ao mesmo tempo em que o discurso dá sinais de reconhecimento de pessoas transexuais, exclui travestis, delineia os critérios para "reconhecer" e se passa como neutro, "isento" de uma ideologia heteronormativa.

Para o reconhecimento de pessoas trans no discurso jurídico dominante ainda são urgentes a necessidade de desnaturalizar a diferença sexual, da revelação da ideologia heteronormativa e o reconhecimento dos direitos de transexuais e travestis. As travestis são as que mais precisam ser reconhecidas, porque ainda são pouco compreendidas. Inclusive na dogmática, pouco são citadas quando falamos de direitos, e nos julgados se observa um senso comum radicalmente ligado a informações populares e distantes da realidade complexa de suas vivências. Ser travesti não é ser um homem que se veste de mulher. É um sujeito que não se adéqua a nenhum dos padrões de homem e de mulher, mas se aproxima mais da categoria inteligível "mulher", por isso requer o reconhecimento de um nome feminino.

Transexuais têm conseguido cada vez mais a retificação do registro civil. A efetividade tem, portanto, aumentado, sem abranger ainda outras identidades não cisgêneras como a travesti. A ideologia heteronormativa explica essa construção simbólica que cria uma fossa abissal entre sujeito e direito, excluindo principalmente a travesti. O senso comum teórico sustenta a transfobia tanto no sistema jurídico quanto fora dele. Se ele usa critérios que negam a subjetividade de pessoas trans e suas situações de discriminação, é porque o discurso dominante social transfóbico ainda prevalece. Por isso a importância de destacar sempre que a cisgeneridade não deve ser pressuposto para os corpos como se fosse uma verdade, principalmente no meio jurídico. Essa verdade é efeito das relações de poder que excluem formas de corporeidades não previstas pelo saber. Assim, a coerência entre sexo, gênero e desejos não precisa ser requisito para que sujeitos sejam reconhecidos como seres humanos, sujeitos de direitos, passíveis de respeito.

Esse senso comum pode ser ressignificado dentro de uma perspectiva que valoriza as histórias de morte de travestis e transexuais, observando a transfobia que ocorre de diversas formas, uma delas sendo a negação do direito ao nome. Como alerta Judith Butler (2010, p. 162): “Nós expandimos nossas noções de direitos para incluir todos, ou nós trabalhamos para construir noções mais robustas de reconhecimento que permitirão alguma forma de relações recíprocas e uma harmonia futura"31 (tradução livre do autor). Essa transfiguração abre espaço para o re-

31 "Whether we expand our existing frameworks or allow them to be interrupted by new vocabularies will determine, in part, how well we consult both the past and the future for our present-day critical practices". 
conhecimento de seres humanos escamoteados da cidadania, abjetos para a sociedade, recuperando a autonomia dos sujeitos ao dar continuidade às diretrizes de bem-estar social para haver menos exclusão e discriminação. Essa mudança não será pura e completamente realizada pelo direito, mas ele pode auxiliar nessa luta na medida em que pode romper com a matriz heteronormativa e verdadeiramente dialogar com as demandas de pessoas trans. Afinal, o registro civil não é o único problema enfrentado por pessoas trans. Os estigmas, todos os tipos de violências e as mortes reverberam na sociedade. Reverter essa situação não será apenas pelo direito e não será apenas para pessoas trans, mas para e por toda sociedade. Não basta enxergar estrategicamente apenas os enunciados de decisões judiciais, é preciso que se entenda a conexão dessa falta de reconhecimento em todo o discurso social que exclui e mata.

"Os mortos da democracia se acumulam. Se a democracia existe, ela não é para todos. [...] É nossa responsabilidade combater esse genocídio" (Caetano, 2016). Afinal, se ainda há decisões no Brasil que negam os pedidos de retificação, questiona-se: estaria o Judiciário isento de promover os objetivos do Estado? Seria uma afronta à igualdade e à liberdade específica de alguém, o reconhecimento da necessidade de igualdade material para pessoas que não são cisgêneras?

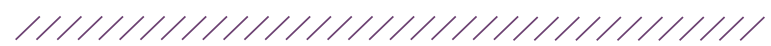

\section{Referências}

Agra, W. de M. (2013). Comentário ao artigo $1^{\circ}$, II. In: J. J. G. Canotilho; G. F. Mendes; I. W. Sarlet; L. L. Streck (Org.). Comentários à Constituição do Brasil. São Paulo: Saraiva/Almedina, 118-121.

Ansara, Y. G.; Berger, I. (2016). Cisgenderism. The Wiley Blackwell Encyclopedia of Gender and Sexuality Studies.

Bento, B (2006). A reinvenção do corpo: sexualidade e gênero na experiência transexual. Rio de Janeiro: Garamond.

Bittar, C. A (2015). Os Direitos da Personalidade. São Paulo: Saraiva.

Butler, J. (2000). Corpos que pesam: sobre os limites discursivos do "sexo". In: LOURO, Guacira Lopes (Org.). O corpo educado: pedagogias da sexualidade. Belo Horizonte: Autêntica, 110-127.

Butler, J. (2001). Doing justice to someone: sex reassignment and allegories of transsexuality. GLQ: $a$ journal of lesbian and gays studies, 7 (4), 621-636.

Butler, J. (2009). Performativity, precarity and sexual politics. AlBR-Revista de Antropologia Iberoamericana, 4 (3), i-xiii.

Butler, J. (2010). Frames of War: When is life grievable?. Nova York e Londres: Verso.

Butler, J. (2014). Problemas de gênero: Feminismo e subversão da identidade. Tradução de Renato Aguiar. 7. ed. Rio de Janeiro: Civilização Brasileira.

Butler, J. (2015). Sem medo de fazer gênero. São Paulo: Folha de São Paulo. Entrevista concedida a Úrsula Passos. Disponível em: <http://www1. folha.uol.com.br/ilustrissima/2015/09/1683172-sem-medo-de-fazer-genero-entrevista-com-a-filosofa-americana-judith-butler.shtml>. Acesso em 15 de julho de 2017.

Carvalho, M.; Carrara, S. (2013). Em direito a um futuro trans?: contribuição para a história do movimento de travestis e transexuais no Brasil. Sex., Salud Soc. (Rio J.), Rio de Janeiro, 14, 319-351.

Comissão Internacional de Juristas; Serviço Internacional pelos Direitos Humanos. Princípios de Yogyakarta: Princípios sobre a aplicação da legislação internacional de direitos humanos em relação à orientação sexual e identidade de gênero de 9 de novembro de 2006. Trad. de Jones de Freitas. Disponível em: < http://www.dhnet.org.br/ direitos/sos/gays/principios_de_yogyakarta.pdf> Acesso em 10 jan. 2017. 
Connel, R.; Pearse, R. (2015). Gênero: uma perspectiva global. Tradução: Marília Moschkovich. São Paulo: nVersos.

Damico, J. (2016). Estado é o maior inimigo das pessoas trans: entrevista. São Paulo: NLUCON. Entrevista concedida a Neto Lucon.

Dominiki, V. (2015). Ser mulher transexual e negra é sofrer duas vezes: entrevista. São Paulo: NLUCON. Entrevista concedida a Neto Lucon.

Fachin, L. E. (2014). O corpo do registro no registro do corpo: mudança de nome e sexo sem cirurgia de redesignação. Revista Brasileira de Direito Civil, 1, jul/set.

Farias, C. C. de; Rosenvald, N. (2016). Curso de Direito Civil: parte geral e LINDB. Salvador: JusPodivm.

Fausto-Sterling, A. (1987). Society Writes Biology / Biology Constructs Gender. In Daedalus, 116 (4), Learning about Women: Gender, Politics, and Power, 61-76.

Favero, S. (2014). Não acreditem nos livros de biologia: entrevista. São Paulo: NLUCON. Entrevista concedida a Neto Lucon.

Filax, G.; Sumara, D.; Davis, B. (2015). Teoria Queer/ Abordagens lésbica e gay. In: B. Somekh, C. Lewin (org.). Teoria e métodos de pesquisa social. Petrópolis: Vozes, 131-140.

Flores, M. V., Duro, R. D., Brum, A. N. (2017). ALTERAÇÃO DO REGISTRO CIVIL DE TRANSEXUAIS: Uma análise empírica do posicionamento do TJ/RS. Revista de Estudos Empíricos em Direito, 4(2).

Fonseca, M. A. (2012). Michel Foucault e o Direto. São Paulo: Saraiva.

Foucault, M. (2013). Vigiar e Punir: História da violência nas prisões. Petrópolis: Vozes.

Foucault, M. (2014). A História da Sexualidade: A vontade de saber. São Paulo: Paz e Terra.

Gagliano, P. S.; Pamplona Filho, R. (2016). Novo curso de direito civil, volume 1: parte geral. São Paulo: Saraiva.

Gonçalves, C. R. (2016). Direito civil brasileiro, volume 1: parte geral. São Paulo: Saraiva.

Jesus, J. G. de (2012). Orientações sobre identidade de gênero: conceitos e termos. Brasília. Disponível em: <https://www.sertao.ufg. $\mathrm{br/up/16/0/ORIENTA \% C3 \% 87 \% C3 \% 95ES}$ P O P U L A \% C $3 \% 87$ \% C $3 \% 830$ _TRAN S. pdf?1334065989>. Acesso em 09 de junho de 2016.
Jesus, J. G. de (2013a). Feminismo e identidade de gênero: elementos para a construção da teoria transfeminista. Seminário Internacional Fazendo Gênero 10 (Anais Eletrônicos). Florianópolis.

Jesus, J. G. de (2013b). Transfobia e crimes de ódio: assassinatos de pessoas transgênero como genocídio. In: Maranhão Fo EMA, organizador. (In) Visibilidade Trans 2. História Agora, 16(2), 101-23. Disponível em: http://jaquejesus.blogspot.com. br/2015/08/transfobia-e-crimes-de-odio.html.

Junior, J. L. (2012). Transitar para onde? Monstruosidade,(des) patologização,(in) segurança social e identidades transgêneras. Estudos feministas, 20(2), 559-568.

Louro, G. L. (2015). Um corpo estranho: ensaios sobre sexualidade e teoria queer. Belo Horizonte: Autêntica.

Lucon, N. (2016). Homem trans negro, Marcelo Caetano se forma pela UnB e emociona em discurso. NLUCON, São Paulo.

Méllo, R.P. (2012). Corpos, heteronormatividade e performances híbridas. Psicologia \& Sociedade; 24 (1), 197-207. Disponível em: <http://www.scielo.br/pdf/psoc/v24n1/22.pdf>. Acesso em 10 de agosto de 2016.

Moore, H. L. (1997) Understanding sex and gender. In Tim Ingold (org.), Companion Encyclopedia of Anthropology. Londres: Routledge, 813-830.

Moraes, F. (2015). Saiam do armário: entrevista. São Paulo: NLUCON. Entrevista concedida a Neto Lucon.

Morando, L. (2014). Por baixo dos panos: repressão a gays e travestis em Belo Horizonte. In J. N. Green, R. Quinalha (Org.). Ditadura e homossexualidade: repressão, resistência e a busca da verdade. São Carlos: EdUFSCar, 53-82.

Nogueira, S. et al. Monitoramento de violências contra pessoas trans no Brasil. Disponível em < http:// redetransbrasil.org/monitoramento.html> Acesso em: 10 jan. 2017.

Rocha, E. G. (2014). Sujeito de direito e subjetividade: reflexões críticas sobre o constitucionalismo democrático. Rio de Janeiro: Lumen Juris.

Sabsay, L. I. (2009). El sujeto de la performatividad: narrativas, cuerpos y políticas en los límites del género. 2008. 480 f. Tese (Doutorado) - Facultat de Filologia, Traducció I Comunicació, Universitat de Valencia, Valencia. 
Sarlet, I. W.. Comentário ao artigo $1^{\circ}$, III. In: J. J. G. Canotilho; G. F. Mendes; I. W. Sarlet; L. L. Streck (Org.). Comentários à Constituição do Brasil. São Paulo: Saraiva/Almedina, 2013.

Siqueira, I. (2016). Destruir, e não me inserir: entrevista. São Paulo: NLUCON. Entrevista concedida a Neto Lucon.

Tepedino, G.; Barboza; H. H.; Moraes, M. C. B. (2007). Código Civil interpretado conforme a Constituição da República. 2 ed. Rio de Janeiro: Renovar.

TRANSGENDER EUROPE (2016). Trans Murder Monitoring Update. Disponível em: <ttp://transrespect. org/en/idahot-2016-tmm-update> Acesso em 10 jan. 2017.

Vartabedian, J. (2014). Migraciones trans: travestis brasileñas migrantes trabajadoras del sexo. cadernos pagu, 42, 275-312.

V., V. (2012). Pela descolonização das identidades trans*.In: VI Congresso Internacional de Estudos sobre a Diversidade Sexual e de Gênero da ABEH (Anais). Salvador: Disponível em: http://bit. ly/1a9bt4h. Acesso em: 17 jul. 2017.

Warat, L. A. (1995). Introdução Geral ao Direito: a epistemologia jurídica da modernidade. Porto Alegre: Sergio Antonio Fabris Editor.

Warat, L. A. (2004a). A ciência jurídica e seus dois maridos in _____. Territórios Desconhecidos: a procura surrealista pelos lugares do abandono do sentido e da reconstrução da subjetividade. Florianópolis: Fundação Boiteux.

Warat, L. A. (2004b). Por quem cantam as sereias, in Territórios Desconhecidos: a procura surrealista pelos lugares do abandono do sentido e da reconstrução da subjetividade. Florianópolis: Fundação Boiteux, 2004b.

Warat, L. A. (2004c). Saber crítico e senso comum teórico dos juristas in . Epistemologia e ensino do direito: o sonho acabou. Florianópolis: Fundação Boiteux.

Warat, L. A. (2009). A digna voz da majestade: Linguística e argumentação jurídica, textos didáticos. Florianópolis: Fundação Boiteux.

Warat, L. A. (2010). A rua grita Dionísio! Rio de Janeiro: Lumen Juris.

Data de submissão/Submission date: 08.08.2017.

Data de aceitação para publicação/Acceptance date: 19.06.2018. 